УДК 73.03

ББК $85.13 ; 63.3(0) 32$

DOI:10.18688/aa155-1-4

Dora Katsonopoulou

\title{
Pathos versus Ideal in Classical Greek Sculpture and the Parian Output
}

The fourth century BC although coupled with the previous fifth century under the term Classical, has been in the past a matter of discussion as to what it really represents. Is it a normal continuation of the fifth century including some further reasonable developments? Is it a transitional period to new trends crystallized in the following Hellenistic era? Is it finally a century of its own separate and distinctive character? Of course, it is not my purpose with today's presentation to return to these questions but to focus on the most characteristic feature of the fourth century art which differentiates it from the preceding fifth century. I am referring to the new style of expressing the emotions of one's soul, i.e. the pathos, in Greek sculpture.

Before going into this discussion, I would like to set shortly the historical background of the era during which the new trends appeared. Classical art flourished within the polis system of the fifth century, the polis conceived as a certain geographic and governmental entity defined by its city-state boundaries and achieving hegemony through a system of alliances. In the fourth century $\mathrm{BC}$, a change took place which led to the transformation from a polis system to imperialism* reaching its peak with the Macedonian rule and Philip II at about 346 BC, when he prevailed over the Greeks politically, and soon after - in 338 BC - militarily. However, the events which mark the beginnings of this change go back even earlier to the late fifth-early fourth century BC, Dionysios the Elder in Syracuse being the earliest example of an autocratic ruler in $405 \mathrm{BC}$. At the same time following the king's Peace in 386, panhellenism became once more a strong ideal among Greeks with Isokrates of Athens as its principal spokesman who delivered his famous oration Panegyrikos in 380 BC. Confederations became then prominent, first the Boeotian in 378, consequently the Arkadian in 371 after the battle at Leuktra. In $377 \mathrm{BC}$, the Athenian League was again revived. The failure of the Leagues to achieve the desired unification against Persia allowed Macedonian power to finally prevail. The city-state under the new rule although did not disappear it entirely became a subordinate element within the much larger imperial system. And when this system by the last decades of the century became immense, the city-state of the previous era retreated as new ideas and notions took over in the life of the Greeks. These were reflected in Greek art through new, non Classical forms.

В русскоязычной историографии термин империализм (imperialism), который использует автор, применяется к иным историческим реалиям. В данном контексте его следует понимать как имперский тип государственного устройства - прим. ред. 
Political changes bringing new attitudes in the Greek society and, therefore, a new style in art are generally accepted as having taken place in the fourth century. Different opinions arise when discussion enters the chronological question. When all these happened? The fourth century is traditionally taken as representing the shift from the Mature Classical to the Late Classical period, the shift chronologically falling between ca 405-375 BC. Historically, the death of Alexander the Great in 323 is generally taken as the end of the Classical period although some other dates have been proposed earlier in the century, as for example $338 \mathrm{BC}$ the date of the battle at Chaironeia, or dates closer to the end of the century around $300 \mathrm{BC}$. In sculpture, there is a general agreement that there was an Early Classical period ca $480-450 \mathrm{BC}$, then a Mature Classical period down to ca 430/29 BC, and then the Rich style entering the early fourth century characterized by a preference for grace and elegance but keeping the traditional Classical rhythms. The style is known from a series of monuments including the Nike Balustrade, the Erechtheion, the temple of Apteros Nike, the temple of Apollo in Phigaleia, the Tholos in Delphi. The themes prevailing, Amazonomachy and Centauromachy, are common in most of these monuments and similarly the use of specific motifs: for example the man advancing in 3-quarter view seen from the rear or advancing to the right but turning his upper body to confront the enemy behind, or the dying Amazon falling from her horse or pulled backward by the hair. It is true, however, that in this style first signs of a new trend can be sensed although still the Classical patterns prevail, as for example in the Nike Balustrade or even more evidently in figures from the Phigaleian frieze.

And although monuments like the Paionios Nike in Olympia or the temple at Phigaleia embody signs of a change, the real breaking off from the Classical formulae can be seen in the Temple of Asklepios at Epidauros. The most striking traits of this change are found in the pedimental sculptures of the east façade and the akroterial figures of the west side, where a new system of forms through body strains and turbulent drapery of figures in contorted movement is present, substantially shifted from the traditional Classical formats still kept mainly in the figures of the west pediment. The sculptures of the east pediment, where the sack of Troy is depicted, are more agitated than those of the west, their draperies more massive, the bodies split into a series of different movements, as seen especially in the figure of Neoptolemos. A comparison with corresponding figures from Phigaleia or from the Nike temple eloquently indicates the absence of the Classical harmonious continuity in Neoptolemos' forms intended to express suffering and passion of participants in a war. Agitation is also shown on the faces of figures involved in such acts, the most expressive of all being the well known head of Priam with his mouth open, teeth shown, eyes and brows distorted to reveal deep pain and sorrow. Nevertheless, it should be noted that first signs of a change, again in the Peloponnese, can also be detected earlier with the Argive-Sikyonian school and, then, more clearly in the sculptures of the temple in Phigaleia and the Nike of Paionios at Olympia.

The Epidaurian sculptures have set the example of the new trend to be recognized in other subsequent works of art and above all in the Tegean temple of Athena Alea in Arkadia, a major architectural project, the work of the renowned Parian sculptor and architect, Skopas ${ }^{2}$. The surviving sculptures from the temple of Athena represent the new powerful style of pathos

2 On the most recent collection of scholarly papers on Skopas and his oeuvre, see [8]. 
identified with Skopas' art expressed via particular facial features and body forms. Skopaic heads following a masonry's clarity in their structuring (as it would be expected from an architect and sculptor) show deep set eyes, swollen eye brows, projected forehead, dilated nostrils, open mouths, and a sharp turn of the neck. The bodies share the same intensity and uneasiness, garments following the expressive moving of body and limbs. Bending and even twisting of bodies to render seizure of a figure by strong emotions was admirably employed by Skopas in his creations, the highly praised Maenad most probably set up in the city of Sikyon in the second quarter of the fourth century BC $[7]^{3}$ being the most demonstrative of all. This new uneasy spirit impressively expressed in the Skopaic Tegean temple, is evident in other places where Skopas also worked. In the Amazonomachy frieze of the Maussolleion for example, where traditional forms and old motifs are still present in poses such as of a Greek advancing in three-quarter view seen from the front or from the rear or fallen to his knee, or of an Amazon pulled back by the hair, there also exist simultaneously new elements of intense movements in the bodies and strong emotion expressed in the faces with deep set eyes and open mouths, most characteristically shown in the Amazon on one of the slabs attributed to the Parian artist, bearing similar features to his famous Maenad but also to Parian sculptures preceding Skopas' age as I will further elaborate below.

Uneasiness and self-involvement also permeate the sensuous figures of a great close contemporary of Skopas, Praxiteles, who developed his own aesthetic within this new spirit of emotion, expressed in dreamy faces, slender sensitive forms and languorous postures of his figures. And although in his earlier works the composition follows more closely the Classical system of contrapposto, as for example in his Satyr pouring wine, new restless rhythms breaking the old Classical harmony are clearly developed by the artist in later works like the Hermes from Olympia or his Eros. The particular means of expressing uneasy mood and sensuality by Praxiteles, and stronger emotions such as agony, suffering and passion by Skopas seem to have been combined so closely in some creations of the two artists, that a number of statues were uncertain already in antiquity as to who was their creator, Skopas or Praxiteles. These works according to Pliny include: the dying Niobids in the temple of Apollo Sosianus, Ianus pater (Hermes Dikephalos) brought from Egypt and dedicated in Augustus' temple, Eros holding the thunderbolt ${ }^{4}$ in the Curia of Octavia. But the new spirit is also present in works created by the third great sculptor of the century and personal artist of Alexander, Lysippos of Sikyon. All six surviving standing figures of the Thessalian Daochos monument dedicated at Delphi represent tension in their postures, Agias in particular with uneasiness expressed in his pose and contemplating face (protruded forehead and especially upturned eyes looking obliquely, set in a Skopaic manner). Internal disquiet is also evident in Alexander's portraits - certainly suitable with Alexander's explosive personality - associated with or derived from Lysippos' works.

Undoubtedly, the new style that prevailed in the fourth century shares principles contrary to the known Classical ones of the previous century. As in life, where individuality superseded the communal feeling, similarly in art Classical tranquility and quiet conceded to more personal sentiments, Classical harmony and continuity to new contrasts and dynamics reflecting the

On the most recent treatment of the Maenad, see [1].

Corso recently revived the attribution of this work to Skopas of Paros [2, p. 436]. 
new sociopolitical conditions of the era. Chronologically, as already mentioned, the beginnings of this change are generally placed ca. $380 \mathrm{BC}$ in the Peloponnese, and exactly in the temple of Asklepios in Epidauros, Timotheos considered to be the instigator of the style near whom Skopas probably received his apprenticeship as a young artist, then in his twenties, as suggested in the past $[8, \text { p. 90 }]^{4}$. The presence of Thrasymedes of Paros as the cult image maker in Epidauros may also have to do with such acquaintance of Skopas with the Epidaurian style. But what is even more striking and has gone unnoticed so far is that the first tendencies toward expressing the new trend in the art of statuary are to be found in works produced in sculpture workshops of Paros, Skopas' own homeland, at a time much prior to the date of the Epidaurian temple.

The exquisite marble statue of a Nike, dated to $470-460$ BC (Ill. 8a) was discovered in the last decades of the $19^{\text {th }}$ century at Kastro (medieval castle) of Paroikia in Paros and is today displayed in the Archaeological Museum of Paros (Room 3) as the central piece of the exhibition. The Parian Nike, "the first 3-dimensional and straining Nike" in ancient Greek sculpture, as the prominent Greek archaeologist $\mathrm{Ch}$. Karouzos characteristically noted in his relative publication last century [3, p. 270], is represented while descending impetuously from the air and is just about to touch the ground with the left foot, the right still suspended. She wears a peplos open to the right side, her head is missing, likewise are the left arm entirely, and the right one from the forearm down, and the wings almost from the roots (Ill. 8b). Her head is supposed to be turned left, the left hand raised, and with the right hand she was holding the edge of her garment open at the right side allowing the youthful body to be seen under the clinging thin drapery. A comparison of the Parian Nike, an early fifth century BC creation of a Parian workshop, with the similar akroterial figure of the Nike from Epidauros of a century later, clearly shows the advancement and pioneering of Parian artists with expressing impulse in movement much earlier than anywhere else "at a time when other schools [of sculpture] do not even consider it" as Karouzos properly described [3, p. 270].

Besides the Nike, another two fine examples of Parian workmanship should be mentioned also dated in the second quarter of the $5^{\text {th }}$ century BC: the torso of a hoplite represented at the moment he is raising his right hand to attack or to defend [10, Fig. 4a, p. 81] and the lower torso of another athlete or hoplite in an impressively rendered 3-dimensional violent move. Indeed, the whole evolution of rendering a figure in impulse can be followed in other Parian examples of the same century on display at the Archaeological Museum of Paros, like the female figure (preserved only in its lower part) advancing to the right, her garment following the body's impetuousness, perhaps an akroterion from a temple of the last quarter of the century; yet another statue of a Nike from the last years of the century shown flying, her transparent garment reeling backwards as it clings on the half-naked body [6, Fig. 5, p. 42; 11, Fig. $5 \mathrm{a}$ and b, p. 82]. But even more amazing is the recent discovery of another marble statue representing a Gorgo dated to the second quarter of the $6^{\text {th }}$ century BC, a whole century before the unique Parian Nike and two centuries before the Epidaurian sculptures (Ill. 9a). The Gorgo was found in the course of systematic excavations carried out in recent years at the site of Agios Panteleimon in Paroikia, and probably belongs to the central akroterion of a temple situated in this area. The figure, a real Parian masterpiece exhibited in the center of Room 1 of the Museum, actually welcoming the visitor as she is placed right across the entrance, descends from the ether in a rush, her wings clashing behind, and has just stepped on with her 
left foot, the right one bent according to the archaic form of these figures. But the Parian artist has achieved to show in the Gorgo a figure in regular move of running (Ill. 9b) unlike the characteristic schematic running of this period, her entire body turned frontward and developed in depth. Another element worth noting about the Gorgo from Paros is her more humane representation expressed by the Parian sculptor via milder facial features as opposed to the fierce representations of the figure known from this period, and an impressively softer attribution of the lower body showing mild curves, and with her garment almost "clinging" on the body as she runs forward vehemently. The work clearly shows that occupation of Parian artists with expressing impetuous movement of a figure in sculpture began already in the Archaic period, at a time much earlier than any other school of sculpture in the Greek world.

There is no doubt that such pioneering works of high quality were in front of Skopas' eyes as he grew up in the island and took apprentice near prominent Parian sculptors. Besides, the artist himself came from a family of sculptors. For Skopas, the first introduction to the style which later became identified with his own distinctive art must have been acquired at the sculpture workshops of his island which produced such masterpieces as the Gorgo or the Nike. Such works must have had a sound impact on Skopas who further developed this art and initiated in sculpture the style of pathos expressed via his marvelous passionate artistic creations. A comparison of the above presented male torso in tension carved by the unknown fifth century Parian artist with the dynamic figure of the Amazon from the Maussolleion attributed to Skopas, and carved about a century later, can show where the origins of this new style should be searched for and to what degree a master sculptor could further evolve sculptural art.

As for Skopas' own age and career in Paros proper, although we cannot attribute with any certainty original works of the $4^{\text {th }}$ century BC from the island to his own hand, certain sculptures exhibited in the Archaeological Museum of Paros are of particular interest in relation to the master and his art. Among them, the most characteristic is a marble head of a bearded male most probably representing the god of medicine Asklepios (Ill. 7) dated around or shortly after the middle of the century [6, pp. 45-46, Figs. 6, 7 $]^{5}$. The head, $27 \mathrm{~cm}$ high, belongs to a slightly over life-size statue probably from the Asklepieion of Paros located at the site of Agia Anna in Paroikia. Strain and disquiet are displayed on the face of the figure expressed via the known Skopaic features, the anxious gaze, in particular, as well as dilated nostrils, and open mouth allowing the teeth to show. The head represents a more "pathetic" depiction of Asklepios which became popular in the second half of the century and later, as shown by a series of known heads among which the characteristic 'Asklepios Blacas' head in the British Museum. Skopas himself made statues of Asklepios and Hygieia for two temples in Arkadia, the temple of Asklepios in Gortys (in this case the god was presented beardless) and of Athena Alea in Tegea. Although the iconography of the Skopaic Asklepios is still escaping us, I wonder if the unknown artist of the marble head from Paros, a possible contemporary of Skopas, follows the Skopaic prototype (lost for us today) of a more "pathetic" representation of the god.

\footnotetext{
5 The statue is further analyzed in my paper entitled A marble head of Asklepios from the Church of Ekatontapyliani of Paros to be presented in the Conference dedicated to the history of the church to be held in Paros in September 2015.
} 
Of course, Skopas being an itinerant artist of his age continuing on a long tradition of Parian sculptors who travelled and worked outside the island as early as at least the sixth century BC and including also his own father and grandfather ${ }^{6}$, assimilated techniques of other workshops and schools to finally shape his own particular style of pathos originating from Paros. No doubt, as the above discussed artistic works show, Parian sculpture workshops set the initiative toward a daring change in the representation of figures in motion, expressed via features characterized by novel agility and elasticity, in a much earlier period than in any other place, and certainly before the date of the Epidaurian sculptures that, until today, are considered to be the first examples of the new style in Greek sculpture of the $4^{\text {th }}$ century BC kept off the Classical forms of the $5^{\text {th }}$ century. Clearly, the statue of the Parian Nike carries these signs of a change already a century earlier than Epidauros, and her predecessor Gorgo indicates the successful undertaking of a 3-dimensional running figure by Parian schools even another hundred years earlier.

Setting out from such a long and rich artistic tradition, it should not come as a surprise to us today that Skopas became the daring introducer of the new spirit in the art of the era, i.e. of the style of pathos which influenced a great deal the course of the Greek sculpture in the following Hellenistic period and beyond. The particular connection of his skill with Paros' artistic legacy is further indicated by the epithet accompanying his name mentioned in ancient

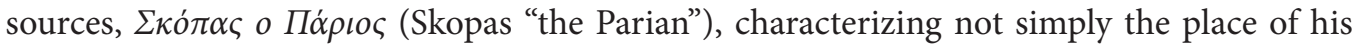
provenance but also his own distinctive "Parian" style.

Название статьи. Пафос versus Идеал в скульптуре классической Греции: патетика в произведениях паросских мастеров.

Сведения об авторе. Кацонопулу Дора - профессор, президент Института археологии Пароса и Кикладских островов, Парикия, Парос, Греция, 84400. paros.iapk@gmail.com

Аннотация. Несмотря на то что традиционно принято объединять IV и V вв. до н. э. в одну классическую эпоху, в действительности IV в. и в историческом, и в художественном смысле от предыдущего принципиально отличен. Это особенно заметно в искусстве и прежде всего - в скульптуре. Именно в ней черты, присущие новым тенденциям, далеким от гармоничных форм и идеальных лиц периода Высокой классики, очевидны с первых его лет. Живые чувства и внутреннее напряжение отныне становятся главным объектом в изображении тел и лиц персонажей. Считается, что эта тенденция, впервые проявившись около 380 г. до н. э. в скульптурах Эпидавра, по мере развития новых приемов передачи пафосных моментов, становится доминирующей к середине столетия. Безусловный отход искусства IV в. до н. э. от классического идеала и обращение к изображению сильных эмоций, видимо, отражает господствующие настроения в социально-политической жизни греков.

С представлениями о новом направлении в искусстве обычно связывают имя близкого современника афинского скульптора Праксителя - Скопаса, выдающегося мастера, родившегося на о. Парос и творившего в 370-330-е гг. до н. э. Автор статьи утверждает, что основы самобытной и плодотворной творческой деятельности Скопаса, как и его стиля следует искать не в Эпидавре IV в. до н. э., а в творчестве паросских мастеров начала V в., приводя в подтверждение своих слов примеры ра-

$6 \quad$ Skopas' most known itinerant forerunners include Aristion of Paros the sculptor of the famous Phrasikleia ( $6^{\text {th }}$ century BC), Agorakritos, the beloved pupil of Pheidias and creator of the Rhamnousian Artemis $\left(5^{\text {th }}\right.$ century $\left.\mathrm{BC}\right)$. Closer to his age - Thrasymedes, the maker of the chryselephantine cult statue of Asklepios in Epidauros ( $4^{\text {th }}$ century BC). Skopas' father Aristandros worked together with Polykleitos in Amyklai in 405 BC (Paus. 3.18.7) and his grandfather of the same name is mentioned by Pliny (NH 34.39) together with other sculptors of the period of ca 420 BC [on Skopas' particular connections with Paros and its cultural environment see: 4, pp. 157-158; 5, pp. 292-299, in connection especially to Archilochos' great heritage]. 
бот паросских скульпторов более раннего времени и предлагая видеть в творческой манере Скопаса определенный «паросский стиль».

Ключевые слова: Скопас; остров Парос; Археологический музей о. Парос; Эпидавр; скульптура; искусство V в. до н. э.; искусство IV в. до н. э.; скульптурные школы; скульптурные традиции; патетика; классический идеал.

Title. Pathos versus Ideal in Classical Greek Sculpture and the Parian Output.

Author. Dora Katsonopoulou - professor, President. The Institute for the Archaeology of Paros and the Cyclades, 84400 Paroikia, Paros, Greece. paros.iapk@gmail.com

Abstract. The fourth century BC although coupled together with the fifth century under the term Classical, is both historically and artistically a different era. Especially in art, particularly the sculpture, new traits are seen already in the early years of the century tending to divert from the Classical harmonious forms and ideal faces of the $5^{\text {th }}$ century. Intensity and vital feelings become now the main tendency expressed in body forms and faces of sculptured figures. This tendency, generally considered as first seen ca $380 \mathrm{BC}$ in the Epidauros sculptures, becomes dominant around the middle of the century when the new style of expressing pathos is well established. The evident departure of the art in the $4^{\text {th }}$ century $\mathrm{BC}$ from the Classical ideal and its turn to the expression of strong emotions seem to reflect new prevailing attitudes in the political and social life of the Greeks.

The sculptor who is mainly associated with the new style and became its real master, is Skopas from the island of Paros, active between 370-330 BC, a close contemporary of Praxiteles of Athens. In the paper it is argued that Skopas' prolific career and distinctive art began in Paros, where the origins of his style are to be found. To this end, certain sculptures from Paros preceding Skopas' age are discussed suggesting that the beginnings of the new trend in sculpture of the $4^{\text {th }}$ century BC should be rather placed in Paros of the early $5^{\text {th }}$ century BC than in Epidauros of the $4^{\text {th }}$ century as considered until today.

Keywords: Skopas; the island of Paros; Archaeological Museum of Paros; Epidauros; sculpture; art of the $5^{\text {th }}$ century BC; art of the $4^{\text {th }}$ century BC; sculptural schools; sculptural tradition; pathos; Classical ideal.

\section{References}

1. Barr-Sharrar B. The Dresden Maenad and Skopas of Paros. Skopas of Paros and His World, Paros III, Proceedings volume of the Third International Conference on the Archaeology of Paros and the Cyclades. Athens, The Institute for the Archaeology of Paros and the Cyclades Publ., 2013, pp. 321-337.

2. Corso A. Cupido fulmen tenens. Skopas of Paros and His World, Paros III, Proceedings volume of the Third International Conference on the Archaeology of Paros and the Cyclades. Athens, The Institute for the Archaeology of Paros and the Cyclades Publ., 2013, pp. 433-442.

3. Karouzos Ch. The Nike of Paros. Nea Estia, 1938, no. 23, pp. 269-271.

4. Katsonopoulou D. Skopas and Paros. Numismatica e antichita classiche, 2004, no. 33, pp. 157-168.

5. Katsonopoulou D. Telephos Arkasides in a New Poem of Archilochos. Archilochos and His Age, Paros II, Proceedings volume of the Second International Conference on the Archaeology of Paros and the Cyclades. Athens, The Institute for the Archaeology of Paros and the Cyclades Publ., 2008, pp. 289-301.

6. Katsonopoulou D. Skopas and Paros (II). Skopas of Paros and His World, Paros III, Proceedings volume of the Third International Conference on the Archaeology of Paros and the Cyclades. Athens, The Institute for the Archaeology of Paros and the Cyclades Publ., 2013, pp. 35-52.

7. Katsonopoulou D. Skopaic Statues of Gods, Demigods and Mortals in Corinthia and the Argolid. Festschrift for Stephen Miller, Athens (in print).

8. Katsonopoulou D.; Stewart A (eds.). Paros III, Proceedings volume of the Third International Conference on the Archaeology of Paros and the Cyclades. Athens, The Institute for the Archaeology of Paros and the Cyclades Publ., 2013. 570 p.

9. Stewart A. F. Skopas of Paros. Park Ridge N. J., Noyess Press Publ., 1977. 183 p.

10. Zaphiropoulou Ph. Sculpture in Paros before Skopas. Skopas of Paros and His World, Paros III, Proceedings volume of the Third International Conference on the Archaeology of Paros and the Cyclades. Athens, The Institute for the Archaeology of Paros and the Cyclades Publ., 2013, pp. 77-91. 